\title{
Ocena wzrostu i stabilności genetycznej agrestu (Ribes grossularia L.) rozmnażanego in vitro oraz ex vitro
}

\author{
Assessment of growth and genetic stability of gooseberry (Ribes grossularia L.) \\ propagated in vitro and ex vitro
}

Danuta Kucharska $^{\oplus}$, Danuta Wójcik ${ }^{\oplus}$, Aleksandra Trzewik $^{\oplus}$

Instytut Ogrodnictwa, Zakład Biologii Stosowanej, ul. Konstytucji 3 Maja 1/3 96-100 Skierniewice

$\bowtie$ e-mail: danuta.kucharska@inhort.pl

\begin{abstract}
Celem badań była ocena fenotypowa i genetyczna roślin 15 genotypów agrestu, rozmnożonych in vitro oraz ex vitro przez sadzonki zielne, uprawianych drugi rok warunkach polowych. Silniej rosły krzewy rozmnożone in vitro. Ich wysokość i liczba pędów były istotnie większe dla 11 genotypów, a szerokość dla 12 genotypów agrestu. Krzewów, na których pojawiły się owoce było znacznie więcej u roślin mnożonych tradycyjnie. Przeprowadzono analizę stabilności genetycznej klonów pochodzących z kultur in vitro pięciu odmian agrestu. Analizowano 13-15 roślin $\mathrm{z}$ in vitro oraz rośliny mateczne. Liczba produktów generowanych przez pary starterów AFLP wahała się od 33 do 108. Najwyższą całkowitą liczbę produktów amplifikacji uzyskano w wyniku reakcji AFLP dla roślin 'Hinnonmaki Rot' (300), a najmniejszą dla odmiany 'Hinsel' i 'Resika' (262). Zmienność genetyczna w roślinach agrestu in vitro wahała się od $1,03 \%$ dla 'Captivator' do $10,3 \%$ w przypadku 'Hinsel'. Stabilność genetyczną oceniano także przy użyciu markerów ISSR. Wykorzystano rośliny 5 genotypów pochodzące z rozmnażania tradycyjnego oraz in vitro. Uzyskano łącznie 2294 produktów amplifikacji, z czego 2,8\% było polimorficznych. Wielkość otrzymanych produktów wynosiła od 250 do 2900 pz, w zależności od startera i odmiany. Analiza ISSR-PCR wskazała na różny stopień polimorfizmu od 0 dla 'Hinnonmaki Rot' i 'Resica' do 11,6\% dla odmiany 'Hinsel'.
\end{abstract}

Slowa kluczowe: AFLP, agrest, DNA, ISSR, kultury in vitro, polimorfizm

The aim of the study was to evaluate phenotypically and genetically, 15 gooseberry genotypes plants propagated in vitro and ex vitro by cuttings grown in the second year in field conditions. The outcome of this was that in vitro propagated shrubs were shown to grew more strongly. Their height and the number of shoots were significantly higher for the 11 genotypes and a width of 12 genotypes for gooseberry. However, fruit abundance was greater in much more traditionally multiplied plants. Beyond the aforementioned, Genetic stability analysis of clones derived from in vitro cultures of five gooseberry varieties was performed. Herein, 13-15 plants with in vitro and mother plants were analyzed. The number of products generated by the AFLP primer pairs ranged from 33 to 108 . The highest total number of amplification products was obtained as a result of the AFLP reaction for the plants ,Hinnonmaki Rot' (300), and the lowest for the varieties ,Hinsel' and ,Resika' (262). Genetic variability in gooseberry in vitro plants ranged from $1.03 \%$ for ,Captivator', to $10.3 \%$ for ,Hinsel'. Genetic stability was also assessed using ISSR markers. Plants of five genotypes derived from conventional and in vitro reproduction were used. Accordingly, a total of 2294 amplification products were obtained, of which $2.8 \%$ were polymorphic. The size of the obtained products was from 250 to $2900 \mathrm{bp}$, depending on the starter and variety. ISSR-PCR analysis showed different degrees of polymorphism - from 0 for the 'Hinnonmaki Rot' and 'Resica' to $11.6 \%$ for the ,Hinsel' variety.

Key words: AFLP, gooseberry, DNA, ISSR, in vitro cultures, polymorphism

\section{Wstęp}

W badaniach prowadzono obserwacje i ocenę fenotypową roślin agrestu rozmnożonych in vitro oraz ex vitro, rosnących w doświadczeniu odmianowo - porównawczym, w warunkach polowych. Analizowano również zmienność somaklonalną 5 genotypów agrestu przy użyciu techniki AFLP oraz jednorodność genetyczną sadzonek in vitro i rozmnożonych tradycyjnie $\mathrm{z}$ zastosowaniem markerów ISSR.

\section{Material i Metody \\ Materiał badawczy stanowiły rośliny} 8 odmian i 7 klonów hodowlanych agrestu, rozmnożone in vitro oraz ex vitro przez sadzonki zielne, rosnące 2 rok w doświadczeniu odmianowo - porównawczym w układzie bloków losowych, w 3 powtórzeniach, po 5 roślin na poletku. Mierzono wysokość, szerokość, liczbę nowych pędów oraz pojawianie się owoców. Dane parametrów wzrostu poddano analizie statystycznej 
przy użyciu jednoczynnikowej analizy wariancji (Statistica 13.1), oddzielnie dla każdego genotypu oraz parametru i porównano za pomocą testu Tukeya przy $\mathrm{p}=0.05$.

Przeprowadzono analizę zmienności genetycznej odmian agrestu: 'Captivator', 'Hinnonmaki Rot', Hinsel', 'Invicta' i 'Resika'. Dla każdej z odmian analizie poddano 13-15 roślin rozmnożonych in vitro oraz rośliny mateczne. Badanie zmienności genetycznej przeprowadzono z wykorzystaniem techniki AFLP według Zabeau i Vos (1993), w dwóch powtórzeniach.

Przeprowadzono także ocenę jednorodności genetycznej sadzonek wegetatywnych i mikrorozmnażanych dla wymieninych odmian. Analizy prowadzono $\mathrm{z}$ wykorzystaniem markerów ISSR. Z każdej odmiany agrestu pobrano młode liście z 10 sadzonek wegetatywnych i 10 sadzonek pochodzących z kultur in vitro. Do izolacji genomowego DNA użyto ok. $100 \mathrm{mg}$ utartej tkanki roślinnej. Izolacje prowadzono $\mathrm{w}$ dwóch powtórzeniach, przy pomocy komercyjnych zestawów: DNeasy® Plant Mini Kit (Qiagen), NucleoSpin ${ }^{\circledR} 96$ Plant kit (Macherey-Nagel) i DNA Plant/Fungi DNA Isolation Kit (Norgen Biotek Corp.). Uzyskane preparaty
DNA analizowano spektrofotometrycznie Epoch (BioTek) i obliczono stężenie genomowego DNA oraz wartość współczynnika 260/280 nm, pozwalającego na ocenę czystości preparatów, które wykorzystano w analizie ISSR-PCR. Amplifikację DNA dla każdego genotypu przeprowadzono dwukrotnie z każdym z 5 wybranych starterów. Oceniono całkowitą liczbę produktów ISSR-PCR, obecność i liczbę produktów polimorficznych oraz obliczono poziom polimorfizmu w badanych genotypach.

\section{Wyniki}

Parametry wzrostu 15 ocenianych genotypów agrestu wskazują, że silniej rosły krzewy rozmnożone in vitro (tab. 1). Wysokość oraz liczba pędów krzewów z in vitro, w porównaniu do rozmnażanych przez sadzonki zielne, były istotnie większe w roślinach 11 genotypów, a szerokość krzewów była istotnie większa w roślinach 12 genotypów. Procent krzewów z owocami był wyższy u roślin ex vitro dla 11 genotypów agrestu.

Liczba produktów generowanych przez pary starterów AFLP wahała się od 33 do 108, średnio wynosiła 52,2. Najwyższą całkowitą liczbę produktów amplifikacji uzyskano dla roślin 'Hinnonmaki

Tabela 1

Table 1

Wysokość, szerokość, liczba pędów i procent roślin z owocami u krzewów agrestu rozmnożonych in vitro oraz ex vitro $(\mathrm{n}=15)$.

Height, width, number of shoots and percentage of plants with fruit in gooseberry bushes propagated in vitro and ex vitro $(\mathbf{n}=15)$.

\begin{tabular}{|c|c|c|c|c|c|c|c|c|}
\hline \multirow[t]{2}{*}{$\begin{array}{l}\text { Genotyp } \\
\text { Genotype }\end{array}$} & \multicolumn{2}{|c|}{$\begin{array}{l}\text { Wysokość }[\mathrm{cm}] \\
\text { Height }[\mathrm{cm}]\end{array}$} & \multicolumn{2}{|c|}{$\begin{array}{l}\text { Szerokość }[\mathrm{cm}] \\
\text { Width }[\mathrm{cm}]\end{array}$} & \multicolumn{2}{|c|}{$\begin{array}{c}\text { Liczba pędów [szt.] } \\
\text { Number of shoots [pcs.] }\end{array}$} & \multicolumn{2}{|c|}{$\begin{array}{l}\text { Rośliny z owocami }[\%] \\
\text { Plants with fruits }[\%]\end{array}$} \\
\hline & In vitro & Ex vitro & In vitro & Ex vitro & In vitro & Ex vitro & In vitro & Ex vitro \\
\hline Biały Triumf & $* 26,9 \mathrm{~b}$ & 19,9 a & $30,6 \mathrm{~b}$ & 18,3 a & $6,2 \mathrm{a}$ & $6,9 \mathrm{a}$ & 0 & 33,0 \\
\hline Captivator & $46,3 \mathrm{a}$ & $48,1 \mathrm{a}$ & $54,7 \mathrm{~b}$ & $49,8 \mathrm{a}$ & $14,0 \mathrm{~b}$ & $7,7 \mathrm{a}$ & 86,7 & 93,3 \\
\hline Hinnonmaki Rot & $36,1 \mathrm{a}$ & $36,2 \mathrm{a}$ & $51,9 \mathrm{a}$ & 53,7 a & $14,2 \mathrm{~b}$ & $10,7 \mathrm{a}$ & 53,3 & 100 \\
\hline Hinsel & $51,3 \mathrm{~b}$ & $37,5 \mathrm{a}$ & $43,3 \mathrm{a}$ & $54,3 \mathrm{~b}$ & $9,8 \mathrm{a}$ & $11,3 \mathrm{a}$ & 6,7 & 53,3 \\
\hline Invicta & $38,2 \mathrm{~b}$ & $30,9 \mathrm{a}$ & $44,1 \mathrm{~b}$ & 37,7 a & $10,1 \mathrm{a}$ & $7,9 \mathrm{a}$ & 20,0 & 66,6 \\
\hline Kamieniar & $31,6 \mathrm{~b}$ & $25,0 \mathrm{a}$ & $37,1 \mathrm{~b}$ & $25,6 \mathrm{a}$ & $10,1 \mathrm{~b}$ & $5,7 \mathrm{a}$ & 13,3 & 60,0 \\
\hline $\operatorname{Pax}$ & $32,2 \mathrm{a}$ & $31,7 \mathrm{a}$ & $42,3 \mathrm{~b}$ & $31,3 \mathrm{a}$ & $11,1 \mathrm{~b}$ & $5,5 \mathrm{a}$ & 0 & 26,6 \\
\hline Resika & $47,6 \mathrm{a}$ & $52,6 \mathrm{~b}$ & 39,7 a & $46,7 \mathrm{~b}$ & $12,1 \mathrm{~b}$ & $7,5 \mathrm{a}$ & 0 & 53,3 \\
\hline AGR-2/2 & $37,1 \mathrm{~b}$ & $30,1 \mathrm{a}$ & $45,5 \mathrm{~b}$ & $37,5 \mathrm{a}$ & $16,0 \mathrm{~b}$ & 6,1 a & 20,0 & 41,7 \\
\hline AGR-2/33 & $37,8 \mathrm{~b}$ & $24,5 \mathrm{a}$ & $49,0 \mathrm{~b}$ & $25,5 \mathrm{a}$ & $12,8 \mathrm{~b}$ & $4,3 \mathrm{a}$ & 60,0 & 23,1 \\
\hline AGR-86 & $48,9 \mathrm{~b}$ & $30,6 \mathrm{a}$ & $60,5 \mathrm{~b}$ & 47,8 a & $12,7 \mathrm{~b}$ & $7,0 \mathrm{a}$ & 20,0 & 0 \\
\hline AGR-101 & $52,0 \mathrm{~b}$ & $22,5 \mathrm{a}$ & $68,5 \mathrm{~b}$ & $25,9 \mathrm{a}$ & $24,9 \mathrm{~b}$ & $4,0 \mathrm{a}$ & 33,3 & 57,1 \\
\hline AGR-102 & $41,7 \mathrm{~b}$ & $26,4 \mathrm{a}$ & $60,7 \mathrm{~b}$ & 28,3 a & $15,9 \mathrm{~b}$ & $5,0 \mathrm{a}$ & 26,6 & 44,4 \\
\hline AGR-108 & $52,2 \mathrm{~b}$ & $37,6 \mathrm{a}$ & $47,8 \mathrm{~b}$ & $33,2 \mathrm{a}$ & $10,2 \mathrm{a}$ & $8,0 \mathrm{a}$ & 0 & 0 \\
\hline AGR-117 & $60,8 \mathrm{~b}$ & $38,8 \mathrm{a}$ & $74,1 \mathrm{~b}$ & $44,7 \mathrm{a}$ & $14,5 \mathrm{~b}$ & $8,5 \mathrm{a}$ & 6,7 & 0 \\
\hline
\end{tabular}

*średnie oznaczone tą samą litera nie różnią się istotnie $p=0,05$ wg testu Tukeya

*means followed by the same letter, were not significantly acc. to Tukey's test. 
Rot' (300), a najmniejszą dla odmian 'Hinsel' i 'Resika' (262). Zmienność genetyczna analizowana metodą AFLP $\mathrm{w}$ roślinach $\mathrm{z}$ in vitro różniła się dla poszczególnych odmian i wahała się od 1,03\% dla odmiany 'Captivator' do $10,3 \% \mathrm{w}$ przypadku odmiany 'Hinsel', w przypadku tej odmiany reakcje AFLP-PCR ze wszystkimi 5 parami starterów generowały produkty polimorficzne. Dla pozostałych odmian produkty polimorficzne uzyskano w reakcji z 2-3 parami starterów (tab. 2, rys. 1).

Uzyskano DNA o stężeniu od 7,8 do 55,1 ng/ $\mu 1$ i wartości współczynnika 260/280 nm od 1,61 do 2,00. W wyniku analizy ISSR-PCR z pięcioma starterami dla 5 badanych genotypów uzyskano łącznie 2294 produktów amplifikacji (tab. 3), z czego 64 (2,8\%) produktów było polimorficznych.

Tabela 2

Table 2

Analiza markerów AFLP w roślinach 5 odmian agrestu pochodzących z kultur in vitro oraz roślin matecznych.

Analysis of AFLP markers in plants of 5 gooseberry cultivars obtained from in vitro and donor plants.

\begin{tabular}{|c|c|c|c|c|}
\hline \multirow{2}{*}{$\begin{array}{l}\text { Odmiana } \\
\text { Cultivar }\end{array}$} & \multirow{2}{*}{$\begin{array}{l}\text { Startery } \\
\text { Primers }\end{array}$} & \multicolumn{2}{|c|}{$\begin{array}{l}\text { Liczba produktów amplifikacji } \\
\text { Number of amplification products }\end{array}$} & \multirow{2}{*}{$\begin{array}{l}\text { Polimorfizm \% } \\
\text { Polymorphism \% }\end{array}$} \\
\hline & & $\begin{array}{l}\text { Całkowita } \\
\text { Total }\end{array}$ & $\begin{array}{l}\text { Polimorficznych } \\
\text { Polymorphic }\end{array}$ & \\
\hline \multirow[t]{5}{*}{ 'Captivator' } & Pst-AT/Mse-CG & 71 & 0 & 0 \\
\hline & Pst-TA/Mse-GA & 103 & 2 & 1,94 \\
\hline & Pst-AGC/Mse-CT & 37 & 0 & 0 \\
\hline & Pst-CAG/Mse-TG & 43 & 0 & 0 \\
\hline & Pst-GTC/Mse-AC & 37 & 1 & 2,70 \\
\hline \multicolumn{2}{|c|}{$\begin{array}{l}\text { Ogółem: } \\
\text { Total: }\end{array}$} & 291 & 3 & 1,03 \\
\hline \multirow[t]{5}{*}{ 'Hinsel' } & Pst-AT/Mse-CG & 60 & 10 & 16,66 \\
\hline & Pst-TA/Mse-GA & 62 & 3 & 4,83 \\
\hline & Pst-AGC/Mse-CT & 47 & 8 & 17,02 \\
\hline & Pst-CAG/Mse-TG & 56 & 4 & 7,14 \\
\hline & Pst-GTC/Mse-AC & 37 & 2 & 5,40 \\
\hline \multicolumn{2}{|c|}{$\begin{array}{l}\text { Ogółem: } \\
\text { Total: }\end{array}$} & 262 & 27 & 10,30 \\
\hline \multirow[t]{5}{*}{ 'Hinnonmaki Rot' } & Pst-AT/Mse-CG & 59 & 0 & 0 \\
\hline & Pst-TA/Mse-GA & 108 & 0 & 0 \\
\hline & Pst-AGC/Mse-CT & 38 & 0 & 0 \\
\hline & Pst-CAG/Mse-TG & 58 & 1 & 1,72 \\
\hline & Pst-GTC/Mse-AC & 37 & 3 & 8,10 \\
\hline \multicolumn{2}{|c|}{$\begin{array}{l}\text { Ogółem: } \\
\text { Total: }\end{array}$} & 300 & 4 & 1,33 \\
\hline \multirow[t]{5}{*}{ 'Invicta' } & Pst-AT/Mse-CG & 58 & 1 & 1,72 \\
\hline & Pst-TA/Mse-GA & 79 & 1 & 1,03 \\
\hline & Pst-AGC/Mse-CT & 41 & 1 & 2,43 \\
\hline & Pst-CAG/Mse-TG & 68 & 0 & 0 \\
\hline & Pst-GTC/Mse-AC & 42 & 0 & 0 \\
\hline \multicolumn{2}{|c|}{$\begin{array}{l}\text { Ogółem: } \\
\text { Total: }\end{array}$} & 288 & 3 & 1,04 \\
\hline \multirow[t]{5}{*}{ 'Resika' } & Pst-AT/Mse-CG & 54 & 1 & 1,85 \\
\hline & Pst-TA/Mse-GA & 36 & 0 & 0 \\
\hline & Pst-AGC/Mse-CT & 33 & 4 & 12,2 \\
\hline & Pst-CAG/Mse-TG & 92 & 0 & 0 \\
\hline & Pst-GTC/Mse-AC & 47 & 2 & 4,25 \\
\hline \multicolumn{2}{|c|}{$\begin{array}{l}\text { Ogółem: } \\
\text { Total: }\end{array}$} & 262 & 7 & 2,67 \\
\hline
\end{tabular}


Table 3

Analiza markerów ISSR w roślinach 5 odmian agrestu pochodzących z kultur in vitro, ex vitro oraz roślin matecznych.

Analysis of ISSR markers in plants of 5 gooseberry cultivars obtained from in vitro, ex vitro and donor plants.

\begin{tabular}{|c|c|c|c|c|c|c|}
\hline \multirow{2}{*}{$\begin{array}{l}\text { Odmiana } \\
\text { Cultivar }\end{array}$} & \multirow{2}{*}{$\begin{array}{l}\text { Starter } \\
\text { Primer }\end{array}$} & \multirow{2}{*}{$\begin{array}{l}\text { Wielkość produktów(pz) } \\
\text { The size of products (bp) }\end{array}$} & \multicolumn{2}{|c|}{$\begin{array}{l}\text { Liczba produktów amplifikacji } \\
\text { Number of amplification products }\end{array}$} & \multirow{2}{*}{\multicolumn{2}{|c|}{$\begin{array}{l}\text { Polimorfizm \% } \\
\text { Polymorphism \% }\end{array}$}} \\
\hline & & & $\begin{array}{l}\text { Ogółem } \\
\text { Total }\end{array}$ & $\begin{array}{l}\text { Polimorficzne } \\
\text { Polymorphic }\end{array}$ & & \\
\hline \multirow{5}{*}{ 'Captivator' } & 822 & $650-1300$ & 63 & 0 & 0 & \\
\hline & 825 & $280-1200$ & 112 & 7 & 6,4 & \\
\hline & 830 & $500-1000$ & 105 & 0 & 0 & 1,4 \\
\hline & 848 & $500-1000$ & 84 & 0 & 0 & \\
\hline & 849 & $500-2900$ & 147 & 0 & 0 & \\
\hline \multirow{5}{*}{$\begin{array}{l}\text { 'Hinnonmaki } \\
\text { Rot' }\end{array}$} & 823 & $450-1100$ & 84 & 0 & 0 & \\
\hline & 825 & $280-1300$ & 126 & 0 & 0 & \\
\hline & 834 & $280-1050$ & 105 & 0 & 0 & 0,0 \\
\hline & 840 & $450-1500$ & 105 & 0 & 0 & \\
\hline & 853 & $700-1400$ & 63 & 0 & 0 & \\
\hline \multirow{5}{*}{,Hinsel’ } & 825 & $250-1300$ & 105 & 4 & 3,8 & \\
\hline & 834 & $500-1200$ & 67 & 5 & 7,5 & \\
\hline & 848 & $500-2500$ & 75 & 17 & 22,7 & 11,6 \\
\hline & 849 & $400-1380$ & 95 & 11 & 11,6 & \\
\hline & 853 & $400-1500$ & 64 & 10 & 15,6 & \\
\hline \multirow{5}{*}{ 'Invicta' } & 821 & $550-2000$ & 47 & 5 & 10,6 & \\
\hline & 825 & $250-1200$ & 90 & 5 & 5,6 & \\
\hline & 834 & $260-750$ & 42 & 0 & 0 & 2,3 \\
\hline & 849 & $400-2000$ & 168 & 0 & 0 & \\
\hline & 853 & $600-1500$ & 84 & 0 & 0 & \\
\hline \multirow{5}{*}{ 'Resika' } & 821 & $350-2000$ & 105 & 0 & 0 & \\
\hline & 822 & $650-1250$ & 63 & 0 & 0 & \\
\hline & 825 & $250-1300$ & 84 & 0 & 0 & 0 \\
\hline & 834 & $500-1200$ & 126 & 0 & 0 & \\
\hline & 849 & $500-1200$ & 84 & 0 & 0 & \\
\hline
\end{tabular}

Wielkości otrzymanych produktów amplifikacji wahały się w granicach $250-2900$ pz, w zależności od startera i odmiany. Zastosowane startery różniły się w ilości generowanych produktów PCR, ich liczba w odmianie 'Invicta' wahała się od 42 dla startera 834 do 168 dla startera 849. Analiza ISSR -PCR wskazała na różny stopień polimorfizmu od jego braku, w przypadku odmian 'Hinnonmaki Rot' i 'Resika', do 11,6\% dla odmiany 'Hinsel' (tab. 3, rys. 2, 3).

\section{Dyskusja}

Parametry wzrostu krzewów odmian i klonów hodowlanych agrestu, w drugim roku wegetacji w warunkach polowych, potwierdzają wpływ sposobu wegetatywnego rozmnażania agrestu przy użyciu sadzonek zielnych lub in vitro ma wpływ na wzrost, pokrój i wigor roślin, a także szybkość wchodzenia w fazę owocowania. $\mathrm{Z}$ wielu doniesień wiadomo, że rośliny pochodzące z kultury in vitro mają większy wigor i bardziej dynamiczny przyrost biomasy (Dubois i in. 1988; Howard i in. 1989; Drew i Smith 1990). Potwierdziły to także nasze obserwacje, w których wysokość, szerokość oraz liczba pędów krzewów agrestu rozmnażanych in vitro były istotnie większe w porównaniu do krzewów rozmnażanych przez sadzonki zielne dla większości genotypów. Nasze obserwacje o bujniejszym wzroście agrestu $\mathrm{z}$ in vitro są pionierskie i potwierdzają doniesienia dotyczące wzrostu innych roślin jagodowych mnożonych in vitro.

Opublikowano wiele doniesień dotyczących zastosowania technik in vitro do namnażania różnych gatunków roślin z rodzaju Ribes (Podwyszyńska i in. 2006, Sedlák i Paprštein 2012, Podwyszyńska i Pluta 2019). Tylko kilka z nich dotyczy 
możliwości efektywnego mnożenia in vitro agrestu (Welander 1985, Wainwright i Flegmann 1986, Reed i Hummer 2002). Kucharska i in. (2020) opisują znaczenie metatopoliny (m-T), zastosowanej zamiast benzyloaminopuryny (BAP), w opracowaniu skutecznej i efektywnej metody mikrorozmnażania 14 genotypów agrestu.

W kulturach in vitro roślin jagodowych utrzymywanych przez dłuższy czas często zdarza się pojawianie zmienności somaklonalnej. Markery molekularne uzyskane przy pomocy technik takich jak: polimorfizm długości fragmentów restrykcyjnych (RFLP), losowo amplifikowany polimorficzny DNA (RAPD), amplifikacja $\mathrm{z}$ udziałem arbitralnych starterów PCR (AP-PCR), fingerprinting, proste sekwencje powtarzalne (SSR) a także polimorfizm długości amplifikowanych fragmentów (AFLP) są wykorzystywane jako narzędzia

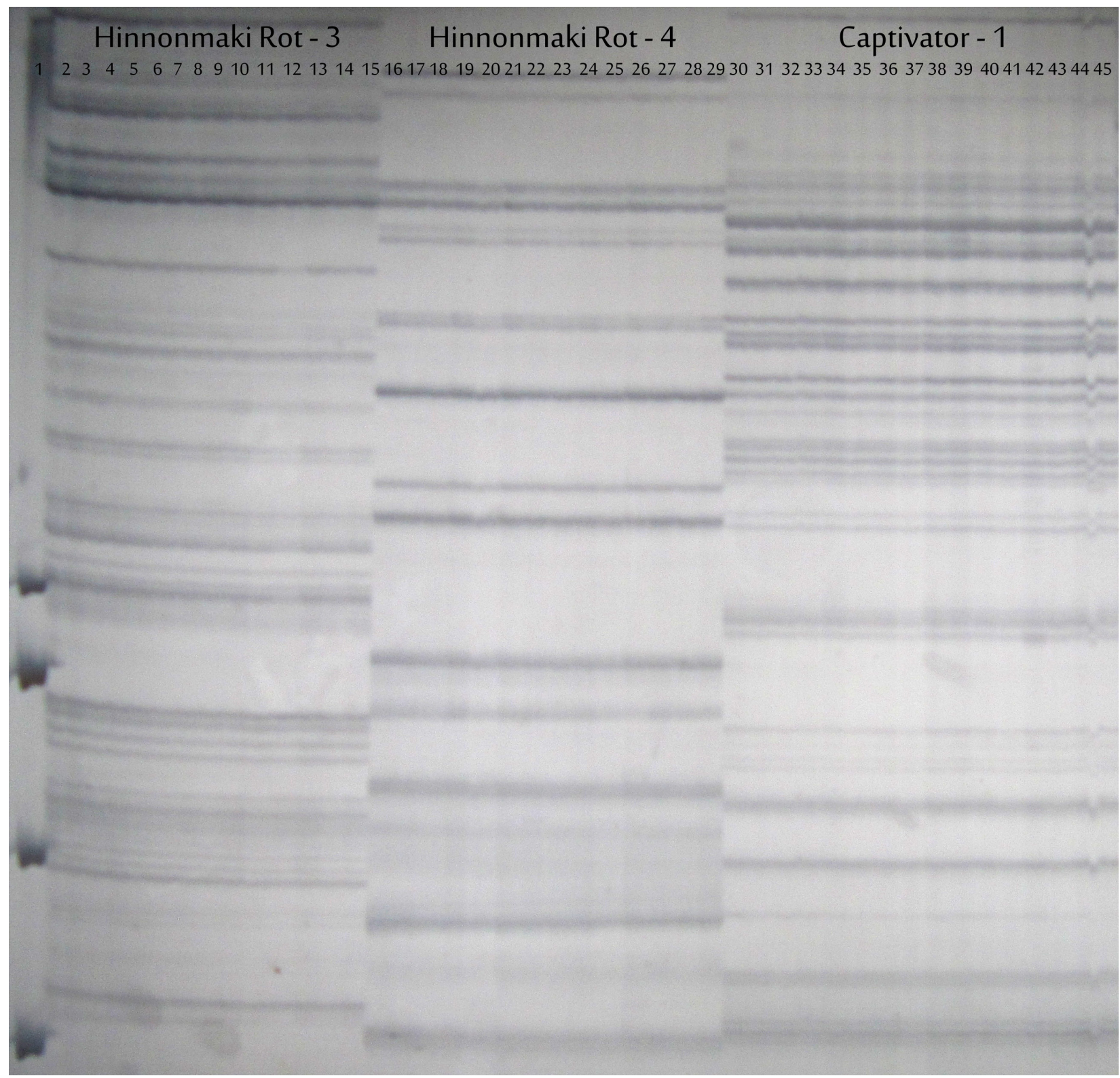

Rys. 1. Fragment elektroforegramu produktów AFLP-PCR; 1 - marker wielkości DNA 50 pz (50 bp DNA Ladder, Thermo Fisher Scientific); 2-15 - reakcja DNA roślin odmiany Hinnonmaki Rot ze starterami Pst-AGC/Mse-CT (2-14 - rośliny z kultur in vitro, 15 - roślina mateczna); 16-29 - reakcja DNA roślin odmiany Hinnonmaki Rot ze starterami Pst-CAG/ Mse-TG (16-28 - rośliny z kultur in vitro, 29 - roślina mateczna); 30-45 - reakcja DNA roślin odmiany Captivator ze starterami Pst-AT/Mse-CG (30-44 - rośliny z kultur in vitro, 45 - roślina mateczna)

Fig. 1. Fragment of electrophoretic banding pattern of AFLP- PCR; 1 - 50 bp DNA Ladder (Thermo Fisher Scientific); 2-15 - reaction of DNA of Hinnonmaki Rot plants with Pst-AGC/Mse-CT primers (2-14 - in vitro-derived plants, 15 - donor plant); 16-29 - reaction of DNA of Hinnonmaki Rot plants with Pst-CAG/Mse-TG primers (16-28 - in vitro-derived plants, 29 - donor plant); 30-45 - reaction of DNA of Captivator plants with Pst-AT/Mse-CG primers (30-44 - in vitro-derived plants, 45 - donor plant) 
do badania zmienności somaklonalnej, ale także do identyfikacji genotypów, badania tożsamości odmianowej oraz określania pokrewieństwa w obrębie wielu gatunków roślin sadowniczych, w tym z rodzaju Ribes (Lanham i Brennan 2001, Brennan i in. 2008, Cavanna i in. 2009). W naszych badaniach zdecydowaliśmy się zastosować technikę AFLP ponieważ została ona uznana za najefektywniejszą w detekcji polimorfizmu DNA u agrestu (Lanham i Brennan, 1999a) oraz jest szeroko stosowana w przypadku u innych gatunków (Bahulikar i in. 2004, Meudt i Clarke 2007, Kumar i in 2013, Costa $\mathrm{i}$ in. 2016).

Markery oparte na DNA uzyskanym w reakcjach RAPD oraz ISSR-PCR były stosowane do scharakteryzowania genotypów skolekcjonowanych w banku genów i używanych w programach hodowlanych IO takich roślin jak: truskawki, jabłonie, porzeczka czerwona i czarna oraz agrest (Korbin i in. 2002). W badaniach nad polimorfizmem 12 odmian agrestu Lanham i Brennan (1999a, 1999b, 2001) wykazali, że użycie starterów ISSR nie pozwoliło na odróżnienie od siebie 3 odmian. W naszych pracach zastosowane startery ISSR pozwoliły na odróżnienie 5 badanych genotypów agrestu. Największy polimorfizm uzyskano dla odmiany 'Hinsel', w której każdy z pięciu testowanych starterów wykazywał obecność produktów polimorficznych (tab. 3, rys. 3). Tak duża zmienność odmiany 'Hinsel', w porównaniu to innych badanych genotypów, świadczy o jej niestabilności genetycznej.

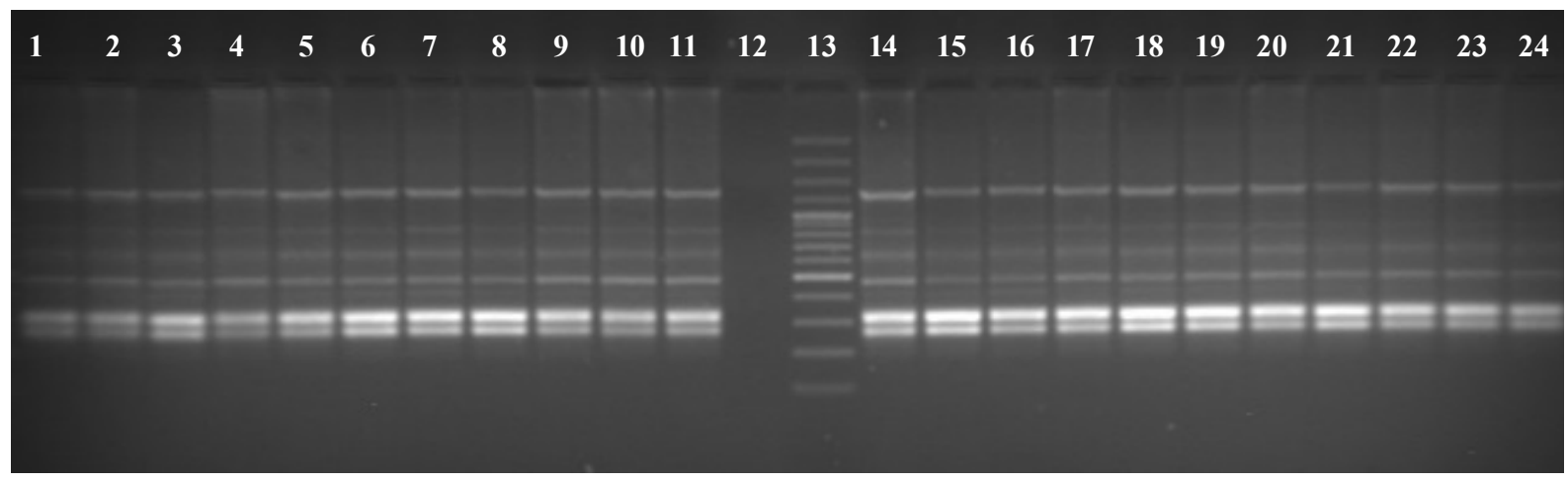

Rys. 2. Elektroforegram produktów PCR z zastosowaniem startera 825 dla odmiany Hinnonmaki Rot, ścieżka 1 i 14: roślina mateczna, 2-11: sadzonki z kultur in vitro, 12: kontrola negatywna, 13: GeneRuler ${ }^{\mathrm{TM}}$ 100bp DNA Ladder Plus (Thermo Fisher Scientific), 14-24 sadzonki wegetatywne

Fig. 2. Electrophoretic banding pattern of PCR products using primer 825 for cultivar Hinnonmaki Rot, lane 1 and 14: donor plant, 2-11: seedlings from cultures in vitro, 12: negative control, 13: GeneRulerTM 100bp DNA Ladder Plus (Thermo Fisher Scientific), 14- 24 vegetative seedlings

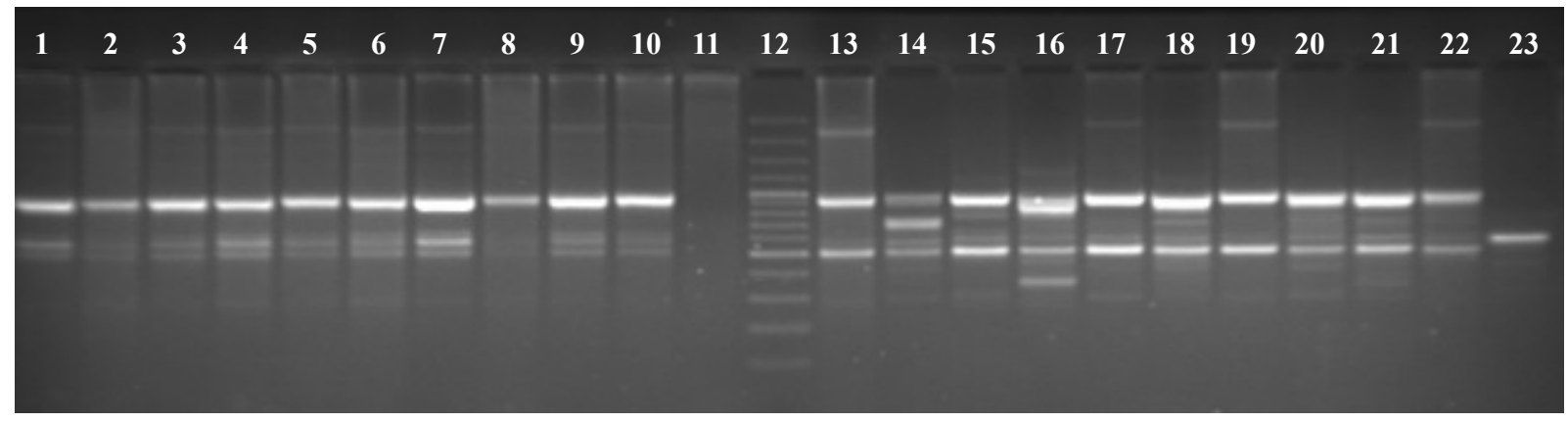

Rys. 3. Elektroforegram produktów PCR z zastosowaniem startera 848 dla odmiany Hinsel, ścieżka 1-10: sadzonki z kultur in vitro, 11: kontrola negatywna, 12: GeneRuler ${ }^{\mathrm{TM}} 100 \mathrm{bp}$ DNA Ladder Plus (Thermo Fisher Scientific), 13: roślina mateczna, 14-23 sadzonki wegetatywne

Fig. 3. Electrophoretic banding pattern of PCR products using primer 848 for cultivar Hinsel, lane 1-10: seedlings from cultures in vitro, 11: negative control, 12: GeneRulerTM 100bp DNA Ladder Plus (Thermo Fisher Scientific), 13: donor plant, 14- 23: vegetative seedlings 


\section{Wnioski}

1. Wysokość, szerokość oraz liczba pędów krzewów $\mathrm{z}$ in vitro, w porównaniu do rozmnażanych ex vitro, były istotnie wyższe dla większości ocenianych genotypów agrestu.

2. Potwierdzono skuteczność techniki AFLP w detekcji stopnia zmienności somaklonalnej u agrestu, generowanej w procesie rozmnażania in vitro.

3. Odmiany 'Captivator', 'Invicta', 'Hinnonmaki Rot' i 'Resika' wykazują stabilność genetyczną w kulturach in vitro. Zastosowanie opracowanej metody mikrorozmnażania agrestu pozwala uzyskać rośliny jednorodne genetycznie.

4. Odmiana 'Hinsel' charakteryzuje się wyższym stopniem zmienności w kulturach in vitro.

Badania finansowano ze środków projektu MRiRW: Badania podstawowe na rzecz postępu biologicznego w produkcji roślinnej na podstawie rozporzadzenia MRiRW z dnia 29 lipca 2015 r. (Dz. U. poz. 1170, z późn. zm.). Zadanie $n r 79$

\section{Literatura}

Bahulikar R.A., Stanculescu D., Preston C.A., Baldwin I.T. 2004. ISSR and AFLP analysis of the temporal and spatial population structure of the post-fire annual, Nicotiana attenuata, in SW Utah. BMC Ecol. 4: 12.

Cavanna M., Marinoni D.T., Beccaro G.L., Bounous G. 2009. Microsatellite-based evaluation of Ribes spp. germplasm. Genome 52(10): 839-848.

Costa R., Pereira G., Garrido I., Tavares-deSousa M.M., Espinosa F. 2016. Comparison of RAPD, ISSR, and AFLP molecular markers to reveal and classify orchardgrass (Dactylis glomerata L.) germplasm variations. PLoS ONE 11(4): e0152972. doi:10.1371/journal. pone. 0152972 .

Drew R.A., Smith M.K. (1990): Field evaluation of tissuecultured bananas in south-eastern Queensland. Austr. J. Exp. Agric., 30: 569-574.

Dubois L.A.M., Roggermans J., Soyeurt G., de Vries D.P. (1988): Comparison of the growth and development of dwarf rose cultivars propagated in vitro and in vivo by softwood cuttings. Sci. Hortic., 55: 293-299.

Howard B.H., Jones O.P., Vasek J. (1989): Long-term improvement in the rooting of plum cuttings following apparent rejuvenation. J. Hort. Sci., 64: 147-156.
Korbin M., Kuras A., Żurawicz E. 2002. Fruit plant germplasm characterisation using molecular markers generated in RAPD and ISSR-PCR. Cell. Mol. Biol. Lett. 7(2B): 785-94.

Kucharska D., Orlikowska T., Maciorowski R., Kunka M., Wójcik D., Pluta S. 2020. Application of meta-topolin for improving micropropagation of gooseberry (Ribes grossularia). Sci. Hort., 272: 109529. https://doi. org/10.1016/j.scienta.2020.109529

Kumar A., Misra P., Dube A. 2013. Amplified fragment length polymorphism: an adept technique for genome mapping, genetic differentiation, and intraspecific variation in protozoan parasites. Parasitol. Res. 112: 457-466.

Lanham P.G., Brennan R.M. 1999a. Genetic characterization of gooseberry (Ribes grossularia subgenus Grossularia) germplasm using RAPD, ISSR and AFLP markers. J. Hort. Sci. Biotech. 74(3): 361-366.

Lanham P.G., Brennan R.M. 1999b. Genetic characterisation of Ribes nigrum, Ribes rubrum and Ribes grossularia. Acta Hort. 505: 385-392.

Lanham P.G., Brennan R.M. 2001. Genetic diversity in Ribes. Acta Hort. 546: 135-137.

Meudt H.M., Clarke A.C. 2007. Almost forgotten or latest practice? AFLP applications, analyses and advances. Trends Plant Sci. 12(3): 106-117.

Podwyszyńska M., Niedoba K., Korbin M., Marasek A. 2006. Somaclonal variation in micropropagated tulips determined by phenotype and DNA markers. Acta Hort. 714: 211-220.

Podwyszyńska M., Pluta S. 2019. In vitro tetraploid induction of the blackcurrant (Ribes nigrum L.) and preliminary phenotypic observations. Zemdirbyste-Agriculture, 106(2), 151-158.

Reed B.M., Hummer K.E. 2002. Cryopreservation of Ribes. W: Towill L.E., Bajaj Y.P.S. (red.), Cryopreservation of Plant Germplasm II. Biotech. in Agriculture and Forestry 50: 323-343.

Sedlák J., Paprštein F. 2012. In vitro establishment and proliferation of red currant cultivars. Hort. Sci. 39: 21-25.

Wainwright H., Flegmann A.W. 1986. Studies on the micropropagation of Ribes species. Acta Horticulturae 183: 315-322.

Welander M. 1985. Micropropagation of gooseberry, Ribes grossularia. Sci. Hort. 26(3): 267-272.

Zabeau M., Vos P., 1993. Selective restriction fragment amplification: a general method for DNA fingerprinting. European Patent Application 92402629.7, Publication number $0534858 \mathrm{~A} 1$. 